\title{
Start-up analysis of partial nitrification process in SBR reactors for different initial conditions
}

\author{
Paula Iliaszewicz $^{1,}$, Stanisław Miodoński ${ }^{1}$ \\ ${ }^{1}$ Faculty of Environmental Engineering, Wroclaw University of Science and Technology, \\ Plac Grunwaldzki 9, 50-377 Wroclaw, Poland
}

\begin{abstract}
There are a lot of technical solutions that are designed to improve the efficiency of nitrogen removal from wastewater. One of the most interesting processes are autotrophic nitrogen removal process ANAMMOX. Essential for the ANAMMOX process is prepare the wastewater containing the correct proportion of ammonium and nitrite. The study tested strategies for start-up of the partial nitrification from wastewater streams from sludge dewatering after the methane fermentation process. The start-up was tested for partial nitrification process from full nitrification process in pilot scale. For the initial conditions was developed strategies. In this strategy was chosen initial parameters such as $\mathrm{pH}$, temperature, and $\mathrm{DO}$ to the partial nitrification process will be well.
\end{abstract}

\section{Introduction}

Over the past several years, there has been intensive development of technology to nitrogen removal from the side stream, due to increased volume of wastewater containing high levels of nitrogen. New technologies provide efficiency of nitrogen removal of over $90 \%[1,2]$. These actions allow for reduction of the nitrogen load, which is directed to the main stream This causes an enhancement of the overall efficiency of nitrogen removal in WWTP. For the removal of nitrogen from the effluent can be trade on conventional processes nitrification and denitrification, which are often implemented in SBR reactors.

The Sequencing Batch Reactors $(S B R)$ are often used for the purification of effluents. They have a lower cost of electricity consumption, a quick start-up period as compared to the flow reactors. Systems are very flexible. Operational parameters can be changed depending on the amount and composition of the influent wastewater [3]. Sewage effluent in the reactor allows to adjust the duration of the cycle, the length phases and time of aeration, depending on the pollutant load. It is relatively easy to keep them constant solid retention time $(S R T)$, by withdrawing a certain amount of excess sludge.

One of many technologies for the removal of nitrogen from the effluent, that trade on this process is ANAMMOX (Anaerobic Ammonium Oxidation) [4]. This process takes place in "specific" anoxic conditions. They lead him bacteria from 5 types: Bracadia, Kuenenia, Scaltndua, Anammoxglobus, Jettenia. It is based on the autotrophic oxidation

*Corresponding author: p.iliaszewicz@gmail.com 
of ammonium nitrogen $\left(\mathrm{N}-\mathrm{NH}_{4}\right)$ to nitrogen gas, by means of an electron acceptor, which are nitrates $\left(\mathrm{N}-\mathrm{NO}_{3}\right)[4,5]$.

Stoichiometry reaction is given by Eq.1

$\mathrm{NH}_{4}^{+}+1.32 \mathrm{NO}_{2}^{-}+0.066 \mathrm{HCO}_{3}^{-}+0.13 \mathrm{H}^{+} \rightarrow$

$$
1.02 \mathrm{~N}_{2}+0.066 \mathrm{CH}_{2} \mathrm{O}_{0.5} \mathrm{~N}_{0.15}+0.26 \mathrm{NO}_{3}^{-}+2.03 \mathrm{H}_{2} \mathrm{O}
$$

For the correctness of the process, it is necessary to provide a substrate into a plant with a molar ratio of $1.3 \mathrm{gN}-\mathrm{NO}_{2} / \mathrm{gN}-\mathrm{NH}_{4}$. This results from stoichiometry reaction (Eq.1). For each 1.32 mole of nitrite there is 1 mole of ammonium nitrogen $[4,5]$. The benefits of the process include no need to provide a source of organic carbon, whereby operating costs are lower. Moreover this process does not cause as much biomass growth. The demand for oxygen is reduced to approximately $40 \%$. That way the energy consumption is reduced. The disadvantages of the ANAMMOX process are a long period of start-up process and the formation of nitrate in influent.

Necessary for the ANAMMOX process is the preparation of wastewater containing suitable proportions of ammonium and nitrite. As a result, it is very important to evaluate the possibility of starting a process of partial nitrification in pilot scale for the wastewater from the dewatering of digested sludge and preparation of the product of partial nitrification, which is a mixture of $\mathrm{N}-\mathrm{NO}_{2}$ and $\mathrm{N}-\mathrm{NH}_{4}$ in a suitable ratio to be able to use generated wastewater to process ANAMMOX.

Nitrification is a microbiological process, which happens in two stages. The oxidation process of ammonia $\left(\mathrm{N}-\mathrm{NH}_{4}\right)$ to nitrites $\left(\mathrm{N}-\mathrm{NO}_{2}\right)$, then to nitrate $\left(\mathrm{N}-\mathrm{NO}_{3}\right)$. Aerobic conditions are very important for the process, oxygen acts as ultimate acceptor of electrons [6]. It takes place in the presence of unrelated groups of autotrophic nitrifying bacteria, which use the energy resulting from the oxidation of ammonia (AOB - Ammonia Oxidizing Bacteria) and nitrite (NOB - Nitrite Oxidizing Bacteria) [7].

The first step of nitrification bacteria carry AOB, which include among others Nitorsomonas, Nitrosococcus, Nitrosospira. It occurs with the participation of ammonia monooxygenase (AMO). Ammonia is oxidized to hydroxylamine $\left(\mathrm{NH}_{2} \mathrm{OH}\right)$, which is the intermediate, then it is oxidized to nitrite $\left(\mathrm{N}-\mathrm{NO}_{2}\right)$, in the presence of hydroxylamine oxidoreductase (HAO) [6].

\section{Analysis strategy of partial nitrification process}

There have been many studies about the start-up of partial nitrification with different parameters such as dissolved oxygen $(D O)$ [8], high temperatures [9], low temperatures [10], free ammonia $(F A)$ and free nitrous acid $(F N A)$ [11].

FA determines the ammonia in the form of undissociated. The amount of FA depends on $\mathrm{pH}$, temperature and concentration of ammonia nitrogen. FA is one of the major factors that inhibit NOB in the process of partial nitrification $[12,13]$. However, the FNA, inhibits the activity of nitrifying bacteria. Inhibition of FNA is the delivery of bacteria into the interior of the additional proton that disrupts the $\mathrm{pH}$ of the both sides of the cell membrane, which then affects the synthesis of ATP [14].

The data presented in Table 1. refer to the start-up of partial nitrification process in the selected parameters. Tests were carried out on different reactors with different volumes. Depending on the solution it can be noticed, that most of the start-ups were below $1 \mathrm{gO}_{2} / \mathrm{m}^{3}$, while $\mathrm{pH}$ oscillated between $6.5 \div 9.0$. Such actions have been obtained for the inhibition of NOB bacteria. In the articles [15, 16, 17, 18, 19, 20, 8, 21, 22] which were focused only on the conditions, which allow to run the process, but composition of effluent 
was not controlled, which could be used in the two-stage deamonification. Ratio $\mathrm{N}-\mathrm{NO}_{2} / \mathrm{N}-\mathrm{NH}_{4}$ was significantly superior to the values of the optimum deamonification process.

Table 1. Characteristics of partial nitrification parameters operational in different experiments.

\begin{tabular}{|c|c|c|c|c|c|c|}
\hline SYSTEMS & NLR $^{1}$ & SRT $^{2}$ & pH & Temp. & DO & $\mathbf{A U R}^{3}$ \\
\hline & $\mathrm{g} \mathrm{N} / \mathrm{m}^{3} \cdot \mathrm{d}$ & $\mathrm{d}$ & - & ${ }^{\circ} \mathrm{C}$ & $\mathrm{g} \mathrm{O}_{2} / \mathrm{m}^{3}$ & $\mathrm{mg} \mathrm{N} / \mathrm{gSS} \cdot \mathrm{h}$ \\
\hline $\begin{array}{l}\text { SBR laboratory, volume } 1.7 \mathrm{dm}^{3} \text {, } \\
\text { synthetic wastewater, controlled DO } \\
\text { using the variable mixing regime, not } \\
\text { controlled ratio } \mathrm{N}-\mathrm{NO}_{2} / \mathrm{N}-\mathrm{NH}_{4}, \\
\text { inhibition of } \mathrm{FA} \text { and FNA, [15] }\end{array}$ & $0.3 \div 1.2$ & - & $7.8 \div 8.1$ & 31 & $<1$ & 1. \\
\hline $\begin{array}{l}\text { Pilot-scale } \mathrm{SBR} \text {, volume } 10 \mathrm{dm}^{3}, \mathrm{PN} / \mathrm{A} \\
\text { process, low-strength swage, not } \\
\text { controlled ratio } \mathrm{N}_{-} \mathrm{NO}_{2} / \mathrm{N}-\mathrm{NH}_{4},[16]\end{array}$ & - & 10 & $7.56 \div 7.71$ & 32 & $<1$ & - \\
\hline $\begin{array}{c}\text { Pilot-scale SBR, volume } 7 \mathrm{~m}^{3} \text {, controlled } \\
\mathrm{pH} \text { and } \mathrm{BF} \text {, low temperature, analysis } \\
\text { FISH, not controlled ratio } \\
\mathrm{N}-\mathrm{NO}_{2} / \mathrm{N}^{-\mathrm{NH}_{4}},[17]\end{array}$ & - & $15 \div 18$ & $6.85 \div 7.85$ & $11 \div 16$ & $>2$ & - \\
\hline $\begin{array}{c}\text { SBR laboratory, volume } 3 \mathrm{dm}^{3} \text {, } \\
\text { wastewater treatment, not controlled } \\
\text { ratio } \mathrm{N}-\mathrm{NO}_{2} / \mathrm{N}-\mathrm{NH}_{4} \text {, inhibition of } \\
\text { nitrate - combination } \mathrm{pH} \text { range and low } \\
\text { DO, [18] }\end{array}$ & - & 11 & $7.5 \div 9.0$ & 32 & $<1$ & $17 \div 22$ \\
\hline $\begin{array}{c}\text { SBR laboratory, wastewater treatment } \\
\text { high } \mathrm{N}-\mathrm{NH}_{4}, \text { not controlled ratio } \\
\mathrm{N}-\mathrm{NO}_{2} / \mathrm{N}-\mathrm{NH}_{4} \text {, different internal } \\
\text { organic carbon sources was tested, } \\
\text { operation of SBR with hydrolysed } \\
\text { primary sludge, [19] }\end{array}$ & - & 11 & $7.5 \div 9.0$ & 32 & $<1$ & 17 \\
\hline $\begin{array}{c}\text { SBR laboratory, volume } 3 \mathrm{dm}^{3}, \\
\text { wastewater treatment, SHARON/DN } \\
\text { and } \mathrm{SBR} \text {, not controlled ratio } \\
\mathrm{N}-\mathrm{NO}_{2} / \mathrm{N}-\mathrm{NH}_{4},[20]\end{array}$ & - & 11 & $7.3 \div 8.1$ & 32 & $<1$ & 22 \\
\hline $\begin{array}{l}\text { SBR laboratory, the effect of regulation } \\
\text { pH, DO and temperature on } \mathrm{PN}, \\
\text { not controlled ratio } \mathrm{N}-\mathrm{NO}_{2} / \mathrm{N}-\mathrm{NH}_{4},[8]\end{array}$ & - & - & $7.0 \div 7.5$ & $<30$ & $<2.5$ & - \\
\hline $\begin{array}{c}\text { Pilot-scale, reactor, inhibition of DO and } \\
\text { FA, not controlled ratio } \\
\text { N-NO }-\mathrm{NO}_{2} / \mathrm{NH}_{4},[21]\end{array}$ & $0.16 \div 2.0$ & 8 & - & 30 & $<2$ & - \\
\hline $\begin{array}{l}\text { Pilot-scale, Reactor AO, inhibition of } \\
\text { FA and FNA, volume } 36 \mathrm{dm}^{3} \text {, not } \\
\text { controlled ratio } \mathrm{N}-\mathrm{NO}_{2} / \mathrm{N}-\mathrm{NH}_{4},[22]\end{array}$ & $0.08 \div 0.66$ & $>35$ & $6.5 \div 8.5$ & - & $2 \div 4$ & - \\
\hline
\end{tabular}

\section{Materials and methods}

\subsection{Reactor design}

Pilot-scale SBR reactor with continuous stirring and aerating has active volume of $150 \mathrm{dm}^{3}$. In the reactor, there was temperature, $\mathrm{pH}$ and DO control. Sludge from excess sludge was injected into the reactor, to keep the appropriate suspended solid concentration and good sedimentation. 


\subsection{Start-up strategy}

Leachate from the belt presses, which dehydrates fermented sludge, was the source of ammonia nitrogen to carry out the experiment.

Start-up of partial nitrification took place in the reactor in which the full nitrification process was run. Parameters were: DO $2 \mathrm{~g} \mathrm{O}_{2} / \mathrm{m}^{3}$, SRT 8 day, temperature $25^{\circ} \mathrm{C}, \mathrm{pH} 7.0$, moreover alkalinity in influent was corrected.

Process was stared based on the analysis of literature. There were made the following steps.

The first and most important activity was turning off the correction of alkalinity in the influent. Then, operating parameters were changed in the reactor: DO $0.8 \mathrm{~g} \mathrm{O}_{2} / \mathrm{m}^{3}$; sludge concentration in the reactor from 3.0 to $2.0 \mathrm{~kg} / \mathrm{m}^{3}$, while the target SRT was 2.5 day (it was not controlled in full nitrification process); the temperature was unchanged $\left(25^{\circ} \mathrm{C}\right)$; $\mathrm{pH}$ was changed to 7.1 .

Analytical monitoring of influent and effluent was performed daily. Moreover concentration of sludge was determined in the reactor. On selected days AUR tests were carried out.

\subsection{Analytical methods}

Analytical monitoring was carried out using a cuvette test and the Hach DR 3900 spectrophotometer. Moreover alkalinity and the sludge concentration were controlled. In order to control the process, AUR tests were performed.

\section{Results and discussions}

The whole experiment lasted 73 days, including 13 days technological break, which was not plant at start of experiment. Nitrogen forms in effluent and NLR during the experiment was shown in Fig. 1.

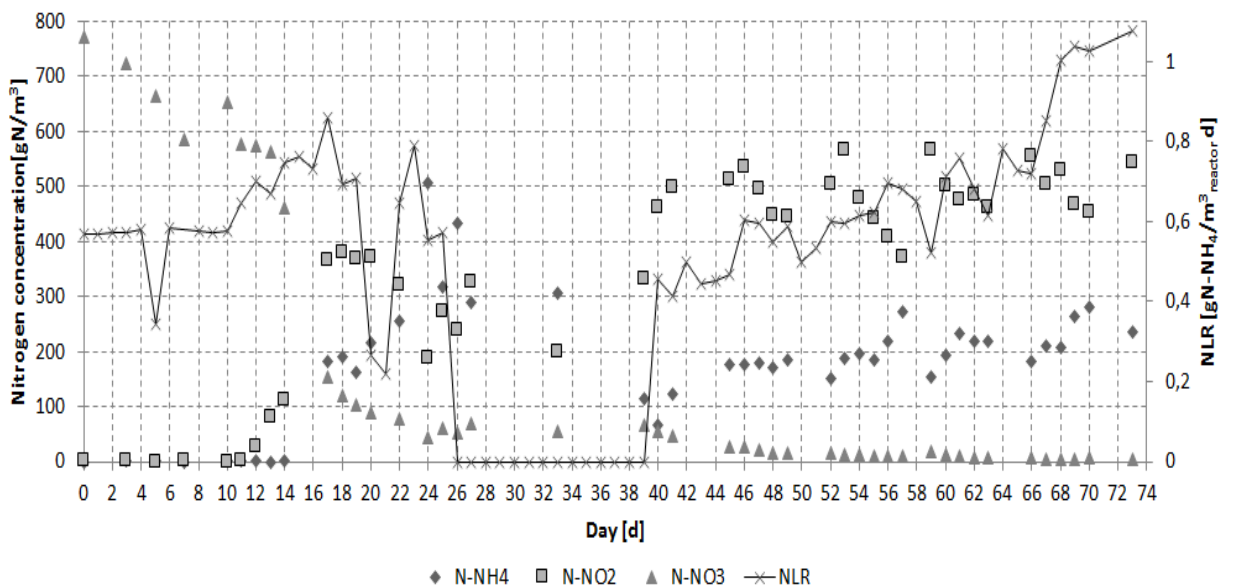

Fig. 1. Profiles of nitrogen concentration and NLR in SBR reactor.

The first 10 days of the experiment was an exploit of full nitrification process without modification of reactor cycle. Based on the strategies described in section 2.2., start-up was carried out on $10^{\text {th }}$ day of experiment.

The reactor was operated according to the strategy to the $25^{\text {th }}$ day. 
In the days $25 \div 45$, it was necessary to stop the reactor, becauseof technological break. The process of the partial nitrification was re-launched in the $45^{\text {th }}$ day. The ratio of $\mathrm{N}-\mathrm{NO}_{2} / \mathrm{N}-\mathrm{NH}_{4}$ with reference to appropriate value for the ANAMMOX process (it has been accepted at $1.2 \mathrm{gN}-\mathrm{NO}_{2} / \mathrm{gN}^{-\mathrm{NH}_{4}}$.), was shown in Fig 2.

Increasing the NLR did not give the desired results. After each increase of NLR, adaptation occurred within $4 \div 6$ days, and from then on it made the ratio $\mathrm{N}-\mathrm{NO}_{2} / \mathrm{N}-\mathrm{NH}_{4}$ worse to values of approx. $3.5 \mathrm{gN}-\mathrm{NO}_{2} / \mathrm{gN}^{-\mathrm{NH}_{4}}$, which cannot be considered as the base ratio. Due to the lack of effects of the target strategies (increasing NLR), there was a decision to lower $\mathrm{pH}$ value in the reactor. This action prevented full adaptation nitrifying bacteria to the new conditions. The effects of the activities has been noticed after 6 days. The value was approximately $2.3 \mathrm{gN}-\mathrm{NO}_{2} / \mathrm{gN}^{-\mathrm{NH}_{4}}$, instead of the primary $3.5 \mathrm{gN}-\mathrm{NO}_{2} / \mathrm{gN}^{-\mathrm{NH}_{4}}$.

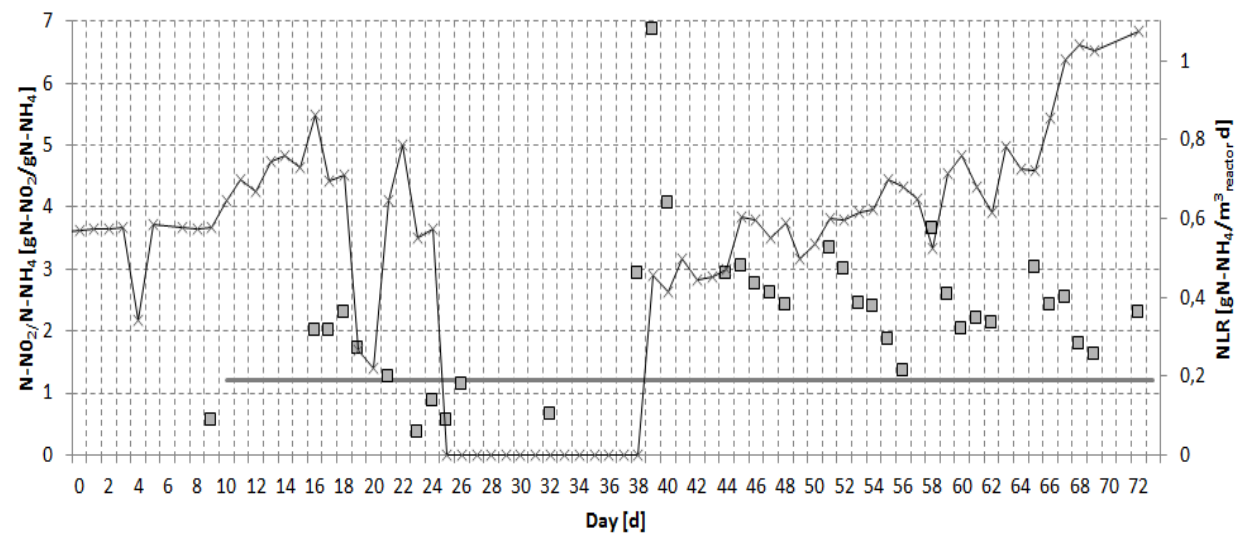

$-\mathrm{N}-\mathrm{NO} 2 / \mathrm{N}-\mathrm{NH} 4$ assumption $\quad \square \mathrm{N}-\mathrm{NO} 2 / \mathrm{N}-\mathrm{NH} 4 \quad * \mathrm{NLR}$

Fig. 2. Profiles of $\mathrm{N}-\mathrm{NO}_{2} / \mathrm{N}-\mathrm{NH}_{4}$ and $\mathrm{NLR}$ in $\mathrm{SBR}$ reactor.

In the days $46 \div 63$ NLR was increased. Each increase in load caused momentary improvement ratio $\mathrm{N}-\mathrm{NO}_{2} / \mathrm{N}-\mathrm{NH}_{4}$, which after $4 \div 5$ days returned to the initial values of approximately $3.5 \mathrm{gN}-\mathrm{NO}_{2} / \mathrm{gN}^{-\mathrm{NH}_{4}}$. The most probable cause of this situation was temporary nitrification overload, and then adaptation of nitrifying bacteria to new conditions. Adaptation of the nitrifying bacteria was noticeable, based on AUR, which was growing in the next days of the experiment (Table 2).

Table 2. Ammonia uptake rate.

\begin{tabular}{|c|c|c|c|c|c|c|c|c|c|c|}
\cline { 3 - 11 } \multicolumn{2}{c|}{} & \multicolumn{9}{c|}{ Days } \\
\cline { 3 - 12 } \multicolumn{2}{c|}{ AUR } & 12 & 14 & 17 & 19 & 47 & 54 & 61 & 67 & 68 \\
\cline { 2 - 12 } & $\mathrm{gN} / \mathrm{m}^{3} \mathrm{~min}$ & 0.66 & 0.70 & 0.19 & 1.17 & 0.14 & 0.21 & 0.34 & 1.29 & 1.08 \\
\hline & $\mathrm{mgN} / \mathrm{gSS} \mathrm{d}$ & 349.7 & 485.8 & 203.5 & 1101.6 & 99.4 & 186.2 & 277.8 & 961.5 & 847.1 \\
\hline
\end{tabular}

Value obtained after adaptation of nitrifying bacteria (at $3.5 \mathrm{gN}-\mathrm{NO}_{2} / \mathrm{gN}^{-\mathrm{NH}_{4}}$ ) meant that nitrification of about $75 \div 80 \%$ of the nitrite was possible, which may be caused by higher alkalinity used in leaching or difficult to determine at this stage impact of $\mathrm{pH}$ adjustment $(\mathrm{NaOH}$ dosage). For this reason, further increasing of the load was pointless, because it probably would not allow to achieve satisfactory results as compared with $\mathrm{N}-\mathrm{NO}_{2} / \mathrm{N}-\mathrm{NH}_{4}$. Such action could lead to the crash of the process.

Because of that, since day 59 to 73 the strategy was modified, and $\mathrm{pH}$ was lowered and maintained in the reactor (change from 7.1 to 6.9). The effect of this action was improve, such as during the increasing of load in the reactor (approximately $1.6 \mathrm{gN}-\mathrm{NO}_{2} / \mathrm{gN}^{-\mathrm{NH}_{4}}$ ). 
The process of adaptation to the new conditions has not been as effective, as in the previous part of the experiment. As the result of these actions, ratio did not return to value of approximately $3.0 \mathrm{gN}-\mathrm{NO}_{2} / \mathrm{gN}_{-} \mathrm{NH}_{4}$, but only to $2.3 \mathrm{gN}-\mathrm{NO}_{2} / \mathrm{gN}^{-\mathrm{NH}_{4}}$ in the last day of the experiment. Given the positive results further action were based on strategies for lowering $\mathrm{pH}$.

Further actions will include gradual lowering of the set $\mathrm{pH}$ value in the reactor until the total shut down of adjustment of $\mathrm{pH}$ or obtaining of satisfactory ratio of $\mathrm{N}-\mathrm{NO}_{2} / \mathrm{N}_{-} \mathrm{NH}_{4}$. Abrupt change is most likely impossible. Shut down of $\mathrm{pH}$ adjustment results in the significant ratio reduction. The high concentration of $\mathrm{N}^{-\mathrm{NO}_{2}}$, which determines a high concentration of FNA, could also lead to inhibition of nitrification of the first phase. It would mean the crash of the process. To prevent lowering of the $\mathrm{pH}$, value should be gradual.

\section{Conclusions}

- The transition from full nitrification process to partial nitrification was very rapid. At that time there was a washout of NOB. After 10 days, the participation of nitrite was $55 \%$ of total $\mathrm{NO}_{\mathrm{x}}$ effluent. After the technological break it was possible to obtain up to $99 \%$ nitrite in total $\mathrm{NO}_{\mathrm{x}}$. The final obtained NLR was approx. $1.05 \mathrm{gN} / \mathrm{m}^{3} \mathrm{~d}$. Probably, there is potential load of SBR reactor, but at this stage it was not the subject of the experiment.

- Attempting to achieve the desired composition of the effluent by increasing the NLR, did not give the desired results. After each increase of NLR, adaptation occurred within $4 \div 6$ days, and from then on it made the ratio $\mathrm{N}-\mathrm{NO}_{2} / \mathrm{N}-\mathrm{NH}_{4}$ worse to values of approx. $3.5 \mathrm{gN}-\mathrm{NO}_{2} / \mathrm{gN}^{-\mathrm{NH}_{4}}$, which cannot be considered as the base ratio. The most probable cause of this situation was temporary nitrification overload, and then adaptation of nitrifying bacteria to new conditions.

The authors gratefully acknowledge co-funding from the National Centre for Research and Development (grant no PBS2/B9/25/2014) and Municipal Water and Sewage Company Wroclaw.

\section{References}

1. E. Arnold, B. Böhm, P.A. Wilderer, Water Sci. Technol. 41, 1 (2000)

2. C. Fux, S. Velten, V. Carozzi, D. Solley, J. Keller, Water Res. 40 (2006)

3. M. Mańczak, Zalety $i$ wady reaktorów okresowego działania $-S B R$, Seminarium nt.:"technologia oczyszczania ścieków w reaktorach SBR - teoria i praktyka (Wyd. Seidel-Przywecki, Warszawa, 2007)

4. A. Mulder, A.A. van de Graaf, L.A. Robertson, J.G. Kuenen, Microbiology Ecology 16 (2006)

5. A.A.Van de Graaf, P. De Bruijn, L.A. Robertson, M.S.M Jetten, J.G. Keunen, Microbiology 142 (1996)

6. Z. Sadecka Podstawy biologicznego oczyszczania ścieków, (Seidel-Przywecki, Piaseczno, 2010)

7. J. Dosta, A. Gali, T.Benabdallah El-Hadj, S. Mace, J. Mata-Alvarez, Bioresource Technol. 98 (2007)

8. J. Wang, N. Yang, Process Biochemistry 39 (2004)

9. C. Hellinga, A. Schellen, J.W. Mulder, J.J Heijnen, Water Sci. Technol. 37 (1998) 
10. S. Gu, S. Wang, Q. Yang, P. Yang, Y. Peng, Bioresoure Technology 112 (2012)

11. S. Park, W. Bae, B.E. Rittmann, Environ. Sci. Technol. 44 (2010)

12. Y. Jeanningros, S. E. Vlaemnick, A. Kaldate., Water Science \& Technology -WST 61 (2010)

13. H. Li., S. Zhou., G. Huang, B. Xu, Process Safety and Environmental Protection 92 (2014)

14. C. Glass, J. Silverstein, J. Oh, Water Environment Research 69 (1997)

15. M. Soliman, A. Eldyasti, , Bioresource Technology 221 (2012)

16. Y. Miao, L. Zhang, Y. Yang, Y. Peng, B. Li, S. Wang, Bioresource Technology 218 (2016)

17. S. Gu, S. Wang, Q. Yang, P. Yang, Y., Bioresource Technology 112 (2012)

18. A. Gali, J. Dosta, J. Mata-Alvarez, .Environ. Technol. 28 (2007)

19. A. Gali, J. Dosta, J. Mata-Alvarez, Ind. Eng. Chem. Res. 45 (2006)

20. A. Gali, J. Dosta, M.C. van Loosdrecht, J. Mata-Alvarez, Ind. Eng. Chem. Res. 45 (2006)

21. J. A. Tora, J. Lafuente, J. Carrer, J. A. Baeza, Environmental Technology 33 (2012)

22. C. Wu, Y. Peng, L. Zhang, Factors Influencing the Start-up and Stability of Partial Nitrification in a Continuous Flow Reactor, (International Conference on Electronics, Communications and Control (ICECC), 2011) 